\title{
Chronic effect of olive oil on some neurotransmitter contents in different brain regions and physiological, histological structure of liver and kidney of male albino rats
}

\author{
A. E. Bawazir
}

Department of Zoology, King Abdul-Aziz University Faculty of Science, Jeddah, Kingdom of Saudi Arabia. Email: maiibriaum@yahoo.com

Received 30 April 2011; revised 7 June 2011; accepted 5 September 2011.

\section{ABSTRACT}

Olive oil is an important source of mono-unsaturated fat and a prime component of the Mediterranean diet. The beneficial health effects of olive oil are due to both its high content of mono-unsaturated fatty acids and its high content of anti-oxidative substances. The objective of this study was to investigate the basis for the epidemiological information relating to the health benefits associated with the consumption of extra-virgin olive oil (EVOO). The effect of olive oil on norepinephrine (NE), dopamine (DA), serotonin (5-HT) and gamm-aminobutyric acid (GABA) contents in different brain regions and histological structure of liver and kindey of male albino rats was studied. The chronic administration of olive oil (7.5 $\mathrm{mg} / \mathrm{kg}$ body wt.) caused a significant increase in norepinephrine (NE), dopamine (DA), serotonin (5-HT) and gamm-aminobutyric acid (GABA) content in different brain regions (Cerebellum, striatum, cerebral cortex, hypothalamus, brain steam and hippocampus) of male albino rats. The increase in NE, DA, 5-HT, and GABA content in the different CNS areas of male albino rat may be due to the inhibition of $\mathrm{Ca}^{2+} /$ calmodulin binding which plays an important role in the release of these neurotransmitters. The results, also, revealed that urea and creatinne concentrations in rats with oral administration with olive oil were decreased. Meanwhile, the activities of the enzymes AsT, AIT and ALP were elevated. The present results indicated that there is no change in tissues of kidney after treated with virgin olive oil. Olive oil may potentially be safe for use as a sedative drug. improvement also led to the reductions in risk of Alzheimer's and Parkinson's diseases.

Keywords: Olive Oil; NE, DA, 5-HT; GABA; Brain Regions; Histological Structure of Liver and Kidney; Male Albino Rats;

\section{INTRODUCTION}

Olive (Olea europaea L.) oil is a fundamental component of the Mediterranean diet (Serra-Majem et al., 2003). In the last few decades there has been a significant increase in the global consumption of olive oil, even in countries where it is not produced, such as the Canada and Japan [1]. This is due in large part to its nutritional and healthpromoting effects [2], which have been related to the optimal balance between saturated, monounsaturated (MUFA), and polyunsaturated fattyacids (PUFA), as well as tominor components such as chlorophyll, polyphenols and tocopherols [3].

Vegetable oils have been historically present in many food stuffs and health care products. it play a leading role in human nutrition, and a source of many essential nutriaents. Vegetable oil is generally obtained from the seeds of plants like soy, sunflower, rape, palm, peanut, corn, etc. Nevertheless, the importance of olive oil, obtained from a drupe fruit, is increasing due to the biological properties of several of its components that preserve health and prevent many degenerative illnesses [4]. Effectively, olive oil has a beneficial effect on the cardiovascular system, lowering the plasma levels of cholesterol and polyunsaturated fatty acids, and decreasing in the same time the risk for low-density-lipoprotein oxidation, which leads to a healthy lipoprotein profile [5]. Furthermore, olive oil diets help in controlling blood pressure, glucose and lipids levels in diabetic patients [6] as well as in improving the immune function by attenuating the inflammatory process [7]. Rojas-Molina et al., [8] and Awney, [9] were tested some vegetable oils in the Drosophila wingspot test and found that extra-virgin olive oil (EVOO) was clearly not genotoxic, while soy oil showed a clear genotoxic activity.

Many studies have been conducted to prove its potential through oil, whole fruit and leaf extract as cardiovascular disorders and anti-oxidant, gastroprotective effect, osteoprotective effect, endocrine effect, immunomodulatory 
effect, anti-cancer, anti-viral and anti-microbial effects and cancers of the breast, skin, and colon [10-12].

Before 1400 years ago the Prophet of Islam, Muhammad (SAW), use of oil is found in many religions and cultures. It has been used during special ceremonies and also as a general health measure. It is also known as the symbol for peace, wisdom and victory [13].

Since olive oil is a wild oil commonly available in Saudi Arabia and especially in the Mediterranean and its leaves are used in folk medicine for treatment, it is therefore deemed interesting to examine the effect of chronic administration of olive oil on norepinephrine (NE), dopamine (DA), serotonin (5-HT) and gamm-aminobutyric acid (GABA) contents in different brain regions and histological structure of liver and kidney of male albino rats.

\section{MATERIALS AND METHOD}

\subsection{Animals}

The experimental animals used in this study were male albino rats, Rattus rattus (90 g - $100 \mathrm{~g}$ ). They were supplied with food and water ad libitum under standard conditions of light, humidity and temperature $\left(22^{\circ} \mathrm{C}-25^{\circ} \mathrm{C}\right)$.

\subsection{Olive Oil}

It is an oil obtained from the olive (Olea europaea; family Oleaceae), a traditional tree crop of the Mediterranean Basin. It is commonly used in cooking, cosmetics, pharmaceuticals, and soaps and as a fuel for traditional oil lamps.

\subsection{Method}

\subsubsection{The Effect of Olive Oil on Different Brain Regions of Male Albino Rats}

The animals were randomly divided into 2 groups. The $1^{\text {st }}$ group $(n=6)$ was treated with saline vehicle and killed at the beginning of the experiment and served as a control. The $2^{\text {nd }}$ group $(\mathrm{n}=24)$ was normal rats orally administered with olive oil $(7.5 \mathrm{ml} / \mathrm{kg})$ through gastric tube for 4 week, [14]. The rat was killed by sudden decapitation at the designed times. The brain was rapidly and carefully excised and then dissected on dry ice glass plate according to the method of Glowinski and Iversen [15] into the following regions: cerebellum, striatum, cerebral cortex, hypothalamus, brain steam and hippocampus. The brain tissues were wiped dry with a filter paper, weighed, wrapped in plastic films and then in aluminum foil and quickly frozen in dry ice pending analysis.

NE, DA and 5-HT were extracted and estimated according to the method of Chang [16] modified by Ciarlone [17]. GABA was estimated according to the method of Sutton and Simmodes [18]. The fluorescence was measured in Jenway 6200 fluorometer.

\subsubsection{The effect of olive oil on liver and kidney function of male albino rats}

Blood Sampling: The portion of blood samples were collected and allowed to coagulate at room temperature; EDTA (ethylene diamine tetracetic acid) was added to the other portion of blood and centrifuged at 3000 r.p.m. for 30 minutes. The clear, non-haemolysed supernatant sera and plasma were quickly removed divided into four portions for each animal, and stored at $-20^{\circ} \mathrm{C}$ for subsequent analysis. For the measurement of AST, ALT and Alkaline phosphatase in liver and, Urea and creatinine in kinday [19].

\subsubsection{The Effect of Olive Oil on Histological Structures of Liver and Kinday of Male Albino Rats}

After sacrifice of animals, part of the liver and kidany tissues from each animal from treated and control was removed and immersed in 10\% buffered formalin solution. Each part of liver and kidney tissues were kept in separate numbered small glass bottles and then embedded in paraffin, and sectioned. Four sections ( 5 microns in thickness) were taken from each liver and kinday tissues, each section being at a distance of at least $500 \mathrm{u}$ from the proceeding one sections were stained with haematoxylin and eosin [20].

\subsubsection{Statistical Analysis}

The data are presented as mean + S.E. Statistical analyses between control and treated animals were performed using paired student ' $\mathrm{t}$ ' [21].

\section{RESULTS}

As shown Table 1 the daily oral administration of olive oil $(7.5 \mathrm{mg} / \mathrm{kg}$ b.wt.) caused a significant increase in dopamine content starting from the third and fourth week in cerebellum, striatum, cerebral cortex, hypothalamus, brain stem and hippocampus. The maximal increase $(\mathrm{p}<0.001)$ in dopamine content was found in the cerebral cortex after 3 weeks $(+103.68 \%)$.

The results obtained from Table 2 showed that the daily oral administration of olive oil caused no significant in nor epinephrine content in all of tested areas after 1, 2, 3 and 4 week. Also, Table 3 showed that the daily oral administration of olive oil $(7.5 \mathrm{mg} / \mathrm{kg}$ b.wt.) caused a significant increase in gamm-aminobutyric acid content starting from the third and four week in cerebellum, striatum, cerebral cortex, hypothalamus, brain stem and hippocampus. The maximal increase in gamm-aminobutyric acid content was found in the cerebral cortex after 4 weeks $(+117.17 \%)$, while the daily oral administration of olive oil caused a significant $(\mathrm{p}<0.001)$ increase in serotonin content starting from two week in brain stem and from the third and four week in all brain area till the end of the experiment. The maximal increase $(p<0.001)$ in serotonin 
Table 1. Effect of chronic oral administration of extra Virgin olive oil (7.5 mg/kg b.wt.) on dopamine (DA) content in the different brain areas of male albino rat.

\begin{tabular}{|c|c|c|c|c|c|c|c|}
\hline \multicolumn{2}{|c|}{$\begin{array}{c}\text { Time of } \\
\text { decapitation }\end{array}$} & $\begin{array}{l}\text { Cerebellum } \\
\text { mean } \pm \text { S.E. }\end{array}$ & $\begin{array}{c}\text { Striatum } \\
\text { mean } \pm \text { S.E. }\end{array}$ & $\begin{array}{c}\text { Cerebral cortex } \\
\text { mean } \pm \text { S.E. }\end{array}$ & $\begin{array}{c}\text { Hypothalamus } \\
\text { mean } \pm \text { S.E. }\end{array}$ & $\begin{array}{l}\text { Brain stem } \\
\text { mean } \pm \text { S.E. }\end{array}$ & $\begin{array}{c}\text { Hippocampus } \\
\text { mean } \pm \text { S.E. }\end{array}$ \\
\hline \multirow{3}{*}{1 week } & $\mathrm{C}$ & $146 \pm 0.082$ & $473.9 \pm 0$ & $60.488 \pm 0.05$ & $754 \pm 2.1$ & $452.29 \pm 0.63$ & $243.14 \pm 086$ \\
\hline & $\mathrm{T}$ & $145.6 \pm 054$ & $476.25 \pm 1.27$ & $60.58 \pm 0.74$ & $726.24 \pm 3.55$ & $453.98 \pm 1.85$ & $241.42 \pm 0.66$ \\
\hline & $\%$ & -0.77 & 0.49 & 0.15 & -1.09 & 0.60 & -0.71 \\
\hline \multirow{3}{*}{2 week } & $\mathrm{C}$ & $145.65 \pm 0.91$ & $485.99 \pm 0.83$ & $61.24 \pm 0.21$ & $739.24 \pm 04.31$ & $451.54 \pm 1.95$ & $244.60 \pm 1.45$ \\
\hline & $\mathrm{T}$ & $158 \pm 0.73$ & $506.17 \pm 1.40$ & $64 \pm 0.26$ & $753.83 \pm 0.79$ & $463.83 \pm 0.91$ & $252.83 \pm 0.95$ \\
\hline & $\%$ & 8.48 & 3.94 & 4.51 & 1.97 & 2.72 & 3.37 \\
\hline \multirow{3}{*}{3 week } & $\mathrm{C}$ & $146.97 \pm 094$ & $474.12 \pm 091$ & $734.057 \pm 2.26$ & $451.61 \pm 059$ & $451.61 \pm 059$ & $242.97 \pm 084$ \\
\hline & $\mathrm{T}$ & $203.16 \pm 095$ & $552.5 \pm 076$ & $123.67 \pm 080$ & $820.17 \pm 01.22$ & $497.67 \pm 1.25$ & $269.83 \pm 0.17$ \\
\hline & $\%$ & 38.23 & 16.53 & 103.68 & 11.73 & 10.20 & 11.06 \\
\hline \multirow{3}{*}{4 week } & $\mathrm{C}$ & $146.1 \pm 1.16$ & $482.78 \pm 3.19$ & $62.32 \pm 0.95$ & $738.21 \pm 4.44$ & $451.63 \pm 64$ & $244.64 \pm 1.54$ \\
\hline & $\mathrm{T}$ & $223 \pm 0.86$ & $598.5 \pm 0.34$ & $126.17 \pm 0.31$ & $820.17 \pm 1.22$ & $498.5 \pm 1.17$ & $272.5 \pm 1.12$ \\
\hline & $\%$ & 52.64 & 23.97 & 102.42 & 11.10 & 10.38 & 11.27 \\
\hline
\end{tabular}

Statistical analyses were performed between control $(\mathrm{C}=6)$ and treated $(\mathrm{T}=6)$ animals by using paired $t$ ' test \%: Percentage of change from control. ${ }^{*}$ : Significant at $\mathrm{p}<0.05$.

Table 2.Effect of chronic oral administration of extra Virgin olive oil (7.5 mg/kg b.wt.) on norepinephrine (NE) content in the different brain areas of male albino rat.

\begin{tabular}{|c|c|c|c|c|c|c|c|}
\hline \multicolumn{2}{|c|}{$\begin{array}{c}\text { Time of } \\
\text { decapitation }\end{array}$} & \multirow{2}{*}{$\begin{array}{c}\begin{array}{c}\text { Cerebellum } \\
\text { mean } \pm \text { S.E. }\end{array} \\
95.382 \pm 0.85\end{array}$} & \multirow{2}{*}{$\begin{array}{c}\begin{array}{c}\text { Striatum } \\
\text { mean } \pm \text { S.E. }\end{array} \\
511.47 \pm 1.8\end{array}$} & \multirow{2}{*}{$\begin{array}{c}\text { Cerebral cortex } \\
\text { mean } \pm \text { S.E. }\end{array}$} & \multirow{2}{*}{$\begin{array}{c}\text { Hypothalamus } \\
\text { mean } \pm \text { S.E. }\end{array}$} & \multirow{2}{*}{$\begin{array}{c}\begin{array}{c}\text { Brain stem } \\
\text { mean } \pm \text { S.E. }\end{array} \\
390.49 \pm 0.48\end{array}$} & \multirow{2}{*}{$\begin{array}{c}\begin{array}{c}\text { Hippocampus } \\
\text { mean } \pm \text { S.E. }\end{array} \\
292.54 \pm 1.54\end{array}$} \\
\hline & $\mathrm{C}$ & & & & & & \\
\hline 1 week & $\mathrm{T}$ & $96.26 \pm 0.79$ & $513.78 \pm 1.08$ & $56.59 \pm 0.73$ & $604.8 \pm 1.59$ & $386.40 \pm 1.86$ & $292.8 \pm 0.64$ \\
\hline & $\%$ & 0.92 & 0.45 & 0.26 & 1.31 & -1.03 & 0.090 \\
\hline \multirow{4}{*}{2 week } & $\mathrm{C}$ & $95.36 \pm 0.86$ & $511.11 \pm 1.65$ & $54.44 \pm 1.9$ & $605.33 \pm 9.5$ & $390.5 \pm 0.48$ & $292.53 \pm 1.53$ \\
\hline & $\mathrm{T}$ & $94.1 \pm 0.78$ & $511.98 \pm 1.21$ & $55.17 \pm 0.31$ & $594.93 \pm 1.15$ & $385.67 \pm 1.87$ & $296.57 \pm 1.42$ \\
\hline & $\%$ & -1.35 & 0.17 & 1.35 & -1.72 & -1.24 & 1.38 \\
\hline & $\mathrm{C}$ & $98.59 \pm 0.27$ & $495.65 \pm 1.44$ & $55.49 \pm 0.11$ & $604.91 \pm 2.33$ & $394.49 \pm 0.94$ & $283.18 \pm 0,82$ \\
\hline \multirow[t]{2}{*}{3 week } & $\mathrm{T}$ & $100.33 \pm 1.23$ & $496.56 \pm 0.93$ & $55.71 \pm 0.48$ & $606.20 \pm 2.14$ & $394.54 \pm 0.89$ & $283.93 \pm 0.83$ \\
\hline & $\%$ & 1.67 & 0.18 & 0.39 & 0.21 & 0.01 & 0.26 \\
\hline \multirow{3}{*}{4 week } & $\mathrm{C}$ & $98.49 \pm 0.27$ & $495.78 \pm 1.4$ & $55.53 \pm 0.13$ & $604.62 \pm 2.26$ & $394.62 \pm 0.94$ & $282.98 \pm 084$ \\
\hline & $\mathrm{T}$ & $97.02 \pm 0.7$ & $496.2 \pm 0.94$ & $56 . \pm 0.96$ & $605.96 \pm 2.10$ & $394.86 \pm 1.25$ & $283.66 \pm 1.10$ \\
\hline & $\%$ & -1.49 & 0.08 & 0.86 & 0.22 & 0.060 & 0.23 \\
\hline
\end{tabular}

Statistical analyses were performed between control $(\mathrm{C}=6)$ and treated $(\mathrm{T}=6)$ animals by using paired $t^{\prime}$ test \%: Percentage of change from control. ${ }^{*}$ : Significant at $\mathrm{p}<0.05$.

Table 3. Effect of chronic oral administration of extra Virgin olive oil ( $7.5 \mathrm{mg} / \mathrm{kg}$ b.wt.) on gamm-aminobutyric acid (GABA) content in the different brain areas of male albino rat.

\begin{tabular}{cccccccc}
\hline $\begin{array}{c}\text { Time of } \\
\text { decapitation }\end{array}$ & $\begin{array}{c}\text { Cerebellum } \\
\text { mean } \pm \text { S.E. }\end{array}$ & $\begin{array}{c}\text { Striatum } \\
\text { mean } \pm \text { S.E. }\end{array}$ & $\begin{array}{c}\text { Cerebral corte } \\
\text { mean } \pm \text { S.E. }\end{array}$ & $\begin{array}{c}\text { Hypothalamus } \\
\text { mean } \pm \text { S.E. }\end{array}$ & $\begin{array}{c}\text { Brain stem } \\
\text { mean } \pm \text { S.E. }\end{array}$ & $\begin{array}{c}\text { Hippocampus } \\
\text { mean } \pm \text { S.E. }\end{array}$ \\
\hline \multirow{3}{*}{1 week } & $\mathrm{C}$ & $192.46 \pm 0.79$ & $171.65 \pm 0.45$ & $57.25 \pm 0.38$ & $432.83 \pm 0.32$ & $118.2 \pm 16$ & $214.79 \pm 1.32$ \\
& $\mathrm{~T}$ & $192.35 \pm 1 . .02$ & $171.69 \pm 1.02$ & $57.92 \pm 0.15$ & $431.39 \pm 2.51$ & $116.81 \pm 0.96$ & $215.27 \pm 0.94$ \\
& $\%$ & -0.06 & 0.02 & 1.17 & -0.33 & -1.14 & 0.22 \\
\multirow{5}{*}{ week } & $\mathrm{C}$ & $192.54 \pm 0.76$ & $171.66 \pm 0.44$ & $57.37 \pm .46$ & $432.93 \pm 0.37$ & $117.87 \pm 0.24$ & $214.93 \pm 1.27$ \\
& $\mathrm{~T}$ & $194 \pm 0.68$ & $176.17 \pm 0.40$ & $60.5 \pm 0.34$ & $435.67 \pm 0.63$ & $124 \pm 0.63$ & $213 \pm 0.45$ \\
& $\%$ & 0.76 & 2.62 & 5.45 & 0.63 & 5.20 & -0.90 \\
3 week & $\mathrm{C}$ & $193.61 \pm 0.78$ & $175.42 \pm 1.78$ & $57.96 \pm 0.68$ & $437.97 \pm 1.1$ & $118.44 \pm .23$ & $216.87 \pm 0.87$ \\
& $\mathrm{~T}$ & $221 \pm 0.58$ & $200 \pm 0.73$ & $83.5 \pm 0.76$ & $483 \pm 0.73$ & $134 \pm 0.73$ & $242.83 \pm 0.7$ \\
& $\%$ & $14.15^{*}$ & $14.01^{*}$ & $44.34^{*}$ & $10.28^{*}$ & $13.70^{*}$ & $11.97^{*}$ \\
& $\mathrm{C}$ & $192.65 \pm 0.42$ & $171.74 \pm 1.62$ & $57.71 \pm 0.93$ & $437.84 \pm 0.19$ & $118.12 \pm 1.39$ & $215.23 \pm 1.1$ \\
& $\mathrm{~T}$ & $221.33 \pm 0.420$ & $200 \pm 0.73$ & $125.33 \pm 0.21$ & $482.83 .79 \pm .79$ & $0144.67 \pm 0.42$ & $0242.66 \pm 0.67$ \\
\end{tabular}

Statistical analyses were performed between control $(\mathrm{C}=6)$ and treated $(\mathrm{T}=6)$ animals by using paired $t^{\prime}$ test \%: Percentage of change from control. ${ }^{*}$ : Significant at $\mathrm{p}<0.05$. 
content was found in the cerebral cortex after 4 weeks $(+114.45 \%)$ (Table 4).

The present results(Table 5) indicated that there are significant $(\mathrm{P}<0.001)$ elevations in the level of aspartate aminotransferase (AST) and alkaline phosphatase in serum of male albino rat treated with olive oil for 4 weeks. This increase was $99.17 \%$ and $557.98 \%$, respectively when compared with control. Also, there are significant $(\mathrm{P}<$ 0.05 ) elevations in the level of alanine aminotransferase (ALT) in serum of male albino rat also was noticed.

Urea content in serum of male albino rat treated with olive oil. (Table 5 ) was significantly $(\mathrm{P}<0.01)$ reduced than in untreated control rat with percentage reduction$56.34 \%$ while creatinine were not significantly changed in treated rate.

The present results showed that (Figure 1) histologycally, Photos sectors in the normal control liver of male albino rat show Casement region of the liver that contains the channel bile (BD) and portal vein (PV) also notes the regularity of bars hepatic cells (HC) on the central vein (CV) and the liver cell contains the central nuclei which contains one or two nucleolus and note pockets vessels (S) which contain cells Kpfer (KC). An enlarged image (Figure 4) of the Figure 3 in the normal liver of male albino rat shows hepatic cells (HC) which contained large spherical and central nuclei, there is most chromatin basal dyes on the inner edge of the membrane of nucleus and some liver nuclei contain one or two nucleus pigmentation strongly dyes basal and also notes that decomposition cytoplasm vacuole for some liver cells. The epithelial cells lining the blood vessels and internal Kpfer cells (KC).

Picture of the sector (Figure 4) in the liver treated with virgin olive oil show that Liver tissue retains the natural composition of the bars in terms of regularity of liver cells $(\mathrm{HC})$ plates are stacked separated by pockets of blood (S). Picture of the sector (Figure 4) in the liver treated with virgin olive oil describes the natural shape of the central vein $(\mathrm{CV})$ and regular bars of liver cells (HC) around him, as they appear Kpfer cells (KC) fusiform natural form..Picture of the sector (Figure 4) in the liver treated with virgin olive oil describes the emergence of good composition of Casement region of the liver and bile ducts regularly (BD) with a slight infiltration of fluid blood in the portal vein (PV).

The present results showed that (Figure 1) histologically, picture of the sector in the kidney cortex control sample shows the renal glomerulus (GL) and the void urine (US) and intertubular urinary (RT) and Figure 2 shows picture of the sector in the kidney cortex control sample show intertubular wrapped nearby (PT) and the edge Alfara-

Table 4. Effect of chronic oral administration oral of Extra Virgin olive oil (7.5 mg/kg b.wt.) on serotonin (5-HT) Content in the different brain areas of male albino rat.

\begin{tabular}{|c|c|c|c|c|c|c|c|}
\hline \multicolumn{2}{|c|}{$\begin{array}{c}\text { Time of } \\
\text { decapitation }\end{array}$} & $\begin{array}{l}\text { Cerebellum } \\
\text { mean } \pm \text { S.E. }\end{array}$ & \multirow{2}{*}{$\begin{array}{c}\begin{array}{c}\text { Striatu } \\
\text { mean } \pm \text { S.E. }\end{array} \\
171.65 \pm 0.45\end{array}$} & \multirow{2}{*}{$\begin{array}{c}\text { Cerebral cortex } \\
\text { mean } \pm \text { S.E. }\end{array}$} & \multirow{2}{*}{$\begin{array}{c}\text { Hypothalamus } \\
\text { mean } \pm \text { S.E. }\end{array}$} & \multirow{2}{*}{$\begin{array}{c}\text { Brain stem } \\
\text { mean } \pm \text { S.E. }\end{array}$} & \multirow{2}{*}{$\begin{array}{c}\begin{array}{c}\text { Hippocampus } \\
\text { mean } \pm \text { S.E. }\end{array} \\
214.79 \pm 1.32\end{array}$} \\
\hline \multirow{3}{*}{1 week } & $\mathrm{C}$ & $192.46 \pm 0.79$ & & & & & \\
\hline & $\mathrm{T}$ & 192. \pm 0.68 & $172.83 \pm 0.87$ & $59.83 \pm 0.54$ & $437.3 \pm 0.54$ & $123.5 \pm 0.84$ & $219.56 \pm 04.52$ \\
\hline & $\%$ & 0.18 & 0.96 & $4.52 *$ & 1.03 & 4.52 & 2.23 \\
\hline \multirow{3}{*}{2 week } & $\mathrm{C}$ & $191.03 \pm 035$ & $170.32 \pm 0.32$ & $56.59 \pm 1.1$ & $433.1 \pm 1.29$ & $118.2 \pm 0.22$ & $213.65 \pm 0.44$ \\
\hline & $\mathrm{T}$ & $191.67 \pm 0.42$ & $171.83 \pm 0.60$ & $58.17 \pm 0.40$ & $436.83 \pm 0.48$ & $132.83 \pm 0.95$ & $224.83 \pm 0.30$ \\
\hline & $\%$ & 0.33 & 0.89 & 2.78 & 0.88 & 12.45 & 5.23 \\
\hline \multirow{3}{*}{3 week } & $\mathrm{C}$ & $191.92 \pm 0.48$ & $173.1 \pm 1.48$ & $57.60 \pm 0.25$ & $433.1 \pm 0.4$ & $117.98 \pm 0.61$ & $214.98 \pm 0.89$ \\
\hline & $\mathrm{T}$ & $212.83 \pm 0.83$ & $219.83 \pm 1.19$ & $115.83 \pm 0.21$ & $481.67 \pm 1.01$ & $131.67 \pm 0.66$ & $242.17 \pm 0.75$ \\
\hline & $\%$ & 10.87 & 27 & 100.22 & 11.24 & 11.6 & 12.66 \\
\hline \multirow{3}{*}{4 week } & $\mathrm{C}$ & $192.86 \pm 0.29$ & $173.1 \pm 1.48$ & $58.1 \pm 0.38$ & $431.43 \pm 1.36$ & $117.87 \pm 0.26$ & $217.16 \pm 0.61$ \\
\hline & $\mathrm{T}$ & $218 \pm 0.93$ & $221.16 \pm 0.79$ & $124.5 \pm 0.22$ & $483.83 \pm 0.83$ & $155.5 \pm 0.34$ & $248.67 \pm 0.42$ \\
\hline & $\%$ & 13.1 & 27.77 & 114.45 & 12.15 & 31.93 & 14.51 \\
\hline
\end{tabular}

Statistical analyses were performed between control $(\mathrm{C}=6)$ and treated $(\mathrm{T}=6)$ animals by using paired $t$ ' test $\%$ : Percentage of change from control. *: Significant at $\mathrm{p}<0.05$.

Table5. Effect of chronic oral administration of Extra Virgin olive oil (7.5 mg/kg b.wt.) on Liver and kidny function of male albino rat.

\begin{tabular}{|c|c|c|c|c|c|c|}
\hline & & $\begin{array}{l}\mathrm{AST}(\mathrm{U} / \mathrm{L}) \\
\text { mean } \pm \text { S.E. }\end{array}$ & $\begin{array}{l}\text { ALT(U/L) } \\
\text { mean } \pm \text { S.E. }\end{array}$ & $\begin{array}{l}\text { Alkaline phosphatase(U/I) } \\
\text { mean } \pm \text { S.E. }\end{array}$ & $\begin{array}{l}\text { Urea }(\mathrm{mg} / \mathrm{dI}) \\
\text { mean } \pm \text { S.E. }\end{array}$ & $\begin{array}{c}\text { Creatinine }(\mathrm{mg} / \mathrm{dI}) \\
\text { mean } \pm \text { S.E. }\end{array}$ \\
\hline \multirow{3}{*}{ 2week } & $\mathrm{C}$ & $99.83 \pm 0.543$ & $78.33 \pm 0.667$ & $60.49 \pm 0.044$ & $97.33 \pm 0.49$ & $0.417 \pm 0.031$ \\
\hline & $\mathrm{T}$ & $199.50 \pm 0.428$ & $97.17 \pm 1.424$ & $400 \pm 0.258$ & $42.67 \pm 0.33$ & $0.450 \pm 0.076$ \\
\hline & $\%$ & $99.83 * * *$ & $24.04 *$ & $561.28 * * *$ & $-56.16 * *$ & 8.0 \\
\hline \multirow[b]{2}{*}{4 week } & $\mathrm{C}$ & $99.833 \pm 0.543$ & $78.33 \pm 0.67$ & $60.49 \pm 0.044$ & $97.33 \pm 0.49$ & $0.417 \pm 0.031$ \\
\hline & $\mathrm{T}$ & $198.833 \pm 0.307$ & $97.17 \pm 1.424$ & $398 \pm 1.61$ & $42.5 \pm 0.438$ & $0.383 \pm 0.031$ \\
\hline
\end{tabular}

Statistical analyses were performed between control $(C=6)$ and treated $(T=6)$ animals by using paired $t$ 'test. \%: Percentage of change from control.*: Significant at $\mathrm{p}<0.05^{*}, * * \mathrm{p}<0.01, * * * \mathrm{p}<0.001$ 


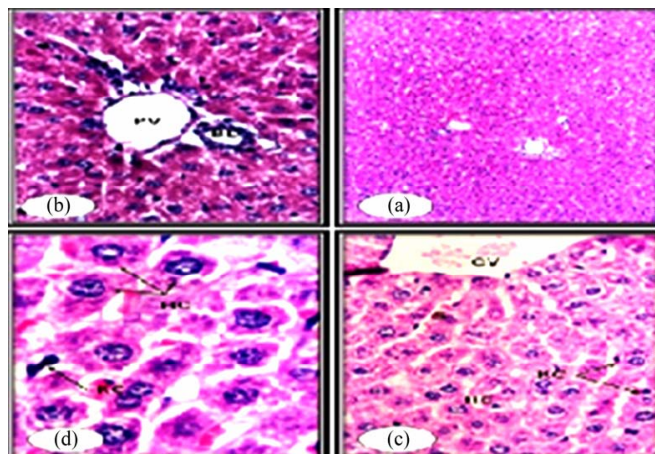

Figure 1. (a), (b) and (c) Photos sectors in the normal control liver of male albino rat: $\mathrm{BD}=$ channel bile, $\mathrm{PV}=$ portal vein, $\mathrm{HC}=$ hepatic cells, $\mathrm{CV}=$ central vein, $\mathrm{S}=$ pockets vessels and $\mathrm{KC}=$ Kpfer cells (haematoxylin and eosin, 100x (1) and 400x (2\&3). (d) an enlarged image of the plate (3) in the normal liver of male albino rat (haematoxylin and eo$\sin , 1000 x$ )

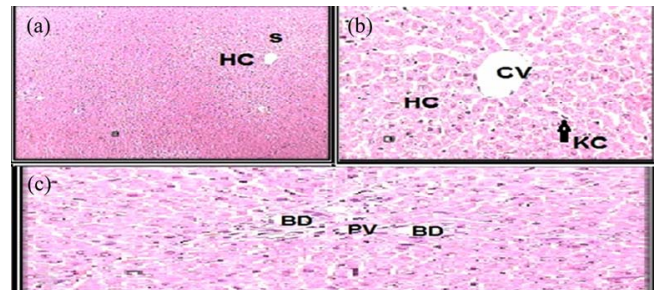

Figure 2. (a) Picture of the sector in the liver treated with virgin olive oil show that Liver tissue retains the natural composition of the bars in terms of regularity of liver cells (HC) plates are stacked separated by pockets of blood (S); (b) Picture of the sector in the liver treated with virgin olive oil describes the natural shape of the central vein $(\mathrm{CV})$ and regular bars of liver cells (HC) around him, as they appear Kpfer cells (KC) fusiform natural form. Hematoxylin dye and Eocene (400x); (c) Picture of the sector in the liver treated with virgin olive oil describes the emergence of good composition of Casement region of the liverand bile ducts regularly (BD) with a slight infiltration of fluid blood in the portal vein (PV) haematoxylin and eosin, (400x).

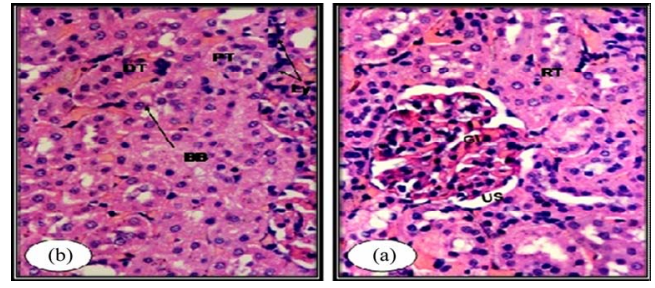

Figure 3. (a) Picture of the sector in the kidney cortex control sample shows the renal glomerulus (GL) and the void urine (US) and intertubular urinary (RT), haematoxylin and eosin, (400x); (b) Picture of the sector in the kidney cortex control sample shows intertubular wrapped nearby (PT) and the edge Alfaragonip (BB) (shares) and intertubular wrapped remote (DT) also notes lymphocytes (Ly) and fibrous tissue interface, haematoxylin and eosin, (400x).

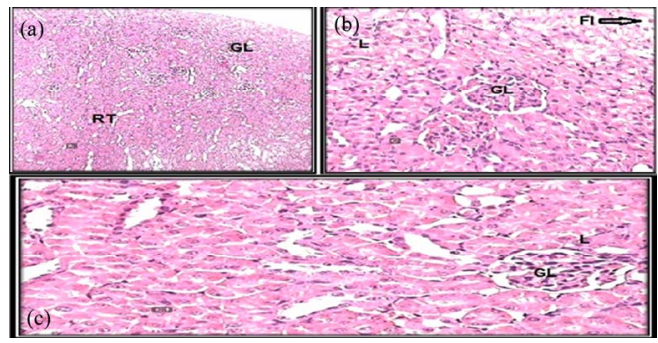

Figure 4. (a), (b) and (c) Piture of the sector in the cortex kidney sample treatment of virgin olive oil describes the emergence of glomeruli urinary (GL) almost naturally as well as a nominated greasy (FI) in most intertubular urinary and simple analyze cytoplasm (CL) with Preserve renal tissue composition of natural, haematoxylin and eosin, $(3=200 x, 4=400 x \& 5=600 x)$.

gonip (BB) (shares) and intertubular wrapped remote (DT) also notes lymphocytes (Ly) and fibrous tissue interface.

The present results indicated that there is no change in tissues of kidney after treated with virgin olive oil, Figure 3 , show that retention of most of the glomeruli and intertubular urinary semi-natural composition, which was described in the control group and did not appear as congestion or stagnation of blood in the tissue interface or expansion of blood vessels (low power). Figure 4 shows that the glomeruli and intertubular urinary form of semi-natural, and bleeding disappeared in the glomeruli and intertubular on urinary (high power).

The Figure 4 shows that intertubular urinary characterized by the nuclei content of the chromatic sems andinatural. There were edges of the cavity coherent and systematic and did not notice any depositions in the cavity of seminifrous intertubular coiled remote with the return of content cytoplasim of the cell and the rule chromatic content active.

\section{DISCUSSION}

The present results showed that oral administration of olive oil caused no significant changes in NE content in all of tested areas after 1, 2, 3 and 4 week. While, it caused a significant increase in dopamine (DA), gamm-aminobutyric acid (GABA) and serotonin (5-HT) content in different brain areas (Cerebellum, striatum, cerebral cortex, hypothalamus, brain steam and hippocampus) of male albino rats. The increase in NE, DA, 5-HT, and GABA content in the different CNS areas of albino rat may be due to the inhibition of $\mathrm{Ca}^{2+} /$ calmodulin binding which plays an important role in the release of neurotransmitters.

The beneficial health effects of olive oil are due to its high content of antioxidative substances, as well as its high content of monounsaturated fatty acids, i.e., oleic acid [22]. oleic acid and linoleic acid (Olive oil) induced increases in free intracellular calcium concentrations $\mathrm{Ca}^{2+}$ by recruiting calcium from endoplasmic reticulum pool via inositol 1, 4, 5-triphosphate production followed by 
calcium influx via opening of store-operated calcium channels. Oleic acid and linoleic acid also induced phosphorylation of Src-protein-tyrosine kinases, particularly of $\mathrm{Fyn}^{59}$ and $\mathrm{Yes}^{62}$. linoleic acid -evoked phosphorylation of Fyn $^{59}$ and Yes $^{62}$ was implicated in the activation of SOC channels. Reverse transcription-quantitative PCR revealed that the CD36-positive gustatory cells possessed mRNA of enzymes like tryptophan hydroxylase-1, L-aromatic amino acid decarboxylase, tyrosine hydroxylase, and dopamine $\beta$-hydroxylase, involved in the synthesis of monoamine neurotransmitters. Interestingly, the addition of linoleic acid to these cells induced the release of 5-hydroxytryptamine and noradrenalin (norepinephrine, nepinephrine) to the extracellular environment.

The linoleic acid induced release of these neurotransmitters was curtailed by SOC channel blockers and SrcPTK inhibitors. These results altogether demonstrate that LA binds to mouse CD36-positive gustatory cells,

It is clear from the literature that DHA is involved in a variety of processes in neural cells and that its role is far more complex than simply influencing cell membrane properties [26]. Unsaturated fatty acids are important constituents of neuronal cell membranes and have neuroprotective, antioxidant, and anti-inflammatory properties [27].

Previous studies had verified their effects on regulating cholesterol levels and hypertension, two risk factors commonly associated with heart disease and Alzheimer's disease.the Polyphenols could prevent damage caused by oxidation or neural death in cell cultures [28].

These results demonstrate that diet contain olive oil is capable of inducing the generation of new cells in the adult brain, and of strengthening the neural networks which become affected with age and in neurogenerative processes such as Alzheimer's disease, as well as protecting neurons from oxidative and neural damage, two phenomena which occur at the origin of many diseases affecting the central nervous system [29]. A study from Germany supports that suspicion, and offers hope that diets high in extra virgin olive oil may help reduce brain damage under the effect of free radicals [30].

The aminotransaminases [aspartate aminotransferase (AST) and alanine aminotransferase (ALT)] represent an important link between carbohydrate and amino acid metabolic pathways [19]. Also, these enzymes are considered good sensitive tools for detection of any variations in the physiological process of living organisms [31,32]. The concentration of these enzymes (AST\&ALT) in liver of treated rats were significantly increased than that in control rat. The elevation in the activities of these enzymes could be due to a variety of conditions including muscle damage, intestinal and hepatic injury and toxic hepatitis [33]. As well, the increase in serum alkaline phosphatase (ALP) activity in patients could be attributed to hepatocytes injury and interruptions in their na- tural activities [33]. Urea content in serum of male albino rat treated with olive oil was depleted reduced than in untreated rat while creatinine was not significantly changed in treated rate.

Elevated liver enzymes are the cause of the destructtion of cells and the occurrence of damage to tissue where attributed scientists Tdmillo liver tissue as a result of increased free radicals and LPO and high enzymes GOT, GPT destruction Bernchimip liver and the accumulation of triglycerides and release enzymes into the bloodstream, which have a clear indication of the emergence of necrosis cell of liver tissue Where scientists attributed the destruction of liver tissue as a result of increased free radicals and LPO and high enzymes GOT, GPT and the accumulation of triglycerides and release enzymes into the bloodstream, which have a clear indication of the emergence of cellular necrosis of the liver tissue [34].

\section{CONCLUSIONS}

Olive oil may potentially be safe for use as a sedative drug improved the central nervous system also led to the reductions in risk of Alzheimer's and Parkinson's diseases. The olive oil could be used as a protector against Alzheimer's and Albarkson a result of the different characteristics.

\section{REFERENCES}

[1] Mili, S. (2006) Olive oil marketing innon-traditionalmarkets: Prospects and strategies. NewMedit, 5, 27-37.

[2] Monteleone, E., Caporale, G., Carlucci, A. and Pagliarini, E. (1998) Optimisation of extra virgin olive oil quality. Journal of the Science of Food and Agriculture, 77, 3137.

doi:10.1002/(SICI)1097-0010(199805)77:1<31::AID-JSF A998>3.0.CO;2-F

[3] Lazzez, A., Perri, E., Caravita, M.A., Khlif, M. and Cossentini, M. (2008) Influence of olive maturity stage and geographical origin on some minor components in virgin olive oil of the Chemlali Variety. Journal of Agricultural and Food Chemistry, 56, 982-988. doi:10.1021/jf0722147

[4] Mackenbach, J.P. (2007) The Mediterranean diet story illustrates that "why" questions are as important as "how" questions in disease explanation. Journal of Clinical Epidemiology, 60, 105-109.

doi:10.1016/j.jclinepi.2006.05.001

[5] Halliwell, B. and Gutteridge, J.M.C. (1999) Free radicals, other reactive species and disease. In: Free Radicals in Biology and Medicine, Third Edition, Oxford University Press, Oxford, 617-783.

[6] Toobert, D.J., Glasgow, R.E., Strycker, L.A., Barrera, M.Jr., Radcliffe, J.L., Wander, R.C. and Bagdade, J.D. (2003) Biologic and quality-of-life outcomes from the Mediterranean lifestyle program: A randomized clinical trial, 
Diabetes Care, 26, 2288-2293. doi: $10.2337 /$ diacare.26.8.2288

[7] Wahle, K.W.J., Caruso, D., Ochoa, J.J. and Quiles, J.L. (2004) Olive oil and modulation of cell signaling in disease prevention. Lipids, 39, 1223-1231. doi:10.1007/s11745-004-1351-y

[8] Rojas-Molina, M., Campos-SJnchez, J., Analla, M., MũnozSerrano, A. and Alonso-Moraga, A. (2005) Genotoxicity of vegetable cooking oils in the drosophila wing spot test. Environmental and Molecular Mutagenesis, 45, 90-95. doi:10.1002/em.20078

[9] Awney, H. (2010) The effect of green tea and olive oil on the mutagenic activity of heterocyclic amines extracted from common food consumed in Saudi Arabia. International Journal of Food Sciences and Nutrition, [Epub ahead of print].

[10] Samova, L.I., Shode, F.O., Ramnanan, P. and Nadar, A. (2003) Antihypertensive, antiatherosclerotic and antioxidantactivity of triterpenoids isolated from Oleaeuropaea, subspecies Africana leaves. Journal of Ethnopharmacology, 84, 299-305. doi:10.1016/S0378-8741(02)00332-X

[11] Owen, R.W., Haubner, R. and Wurtele, G. (2004) Olives and olive oil in cancer prevention. European Journal of Cancer Prevention, 13, 319-326. doi:10.1097/01.cej.0000130221.19480.7e

[12] Omar, S.H. (2008) Pharmacy department, sebai institute of health. Pharmacognosy reviews, 2, 96-100.

[13] Omar, S.H. (2010) Oleuropein in olive and its pharmacological effects. Scientific Pharmaceuticals, 78, 133154. doi:10.3797/scipharm.0912-18

[14] Luciane, A., Faine, H., Rodrigues, G., Cristiano Galhardi, M., Geovana, M. and Ebaid, X. (2006) Effects of olive oil and its minor constituents on serum lipids, oxidative st. Canadian Journal of Physiology and Pharmacology, 84, 239. doi: $10.1139 / \mathrm{y} 05-124$

[15] Glowinski, J. and Iversen, L.L. (1966) Regional studies catecholamines in the rat brain I. The disposition of [3H] norepinephrine, $[3 \mathrm{H}]$ dopamine and $[3 \mathrm{H}]$ dopa in various regions of the brain. Journal of Neurochemistry, 13, 655-669. doi:10.1111/j.1471-4159.1966.tb09873.x

[16] Chang, C.C. (1964) Asensitive method for spectrophoto metric assay of catecholamines. International Journal of Neuropharmacology, 3, 643-649. doi:10.1016/0028-3908(64)90089-9

[17] Ciarlone, A.E. (1978) Further modification of a fluorometric method for analyzing brain amines. Microchemical Journal, 23, 9-12. doi:10.1016/0026-265X(78)90034-6

[18] Sutton, I. and Simmonds, M.A. (1973) Effects of acute and chronic ethanol on the gama-aminobutyric acid system in rat brain. Biochemical Pharmacology, 22, 1685 1692. doi:10.1016/0006-2952(73)90381-X

[19] Christic, J.H. and Michelson, E.H. (1978) Transaminase levels in the digestive gland-gonad of Schistosoma mansoni infected Biomplalaria alexandrina. Comparative Physiology and Biochemistry, 50, 233-236.

[20] Harris, H.F. (1900) On the rapid conversion of haematoxylin into haematin staining reactions. Journal of Applied Microscopy and Laboratory Methods, 3, 777.

[21] Hill, H.B. (1971) Principles of medical statistics. 9th Edition, Oxford University Press.

[22] Pérez-Jiménez, F., Ruano, J., Perez-Martinez, P., Lo-
pez-Segura, F. and Lopez-Miranda, J. (2007) The influence of olive oil on human health: Not a question of fat alone. Molecular Nutrition and Food Research, 51, 1199-1208.

[23] Abdelghani, E.-Y., Aziz, H., Philippe, B. and Khan, N.A. (2008) Linoleic acid induces calcium signaling, src kinase phosphorylation, and neurotransmitter release in mouse CD36-positive gustatory cells. Journal of Biological Chemistry, 283, 12949-12959. doi:10.1074/jbc.M707478200

[24] Visoli, F., Poli, A. and Gall, C. (2002) Antioxidant and other biological activities of phenols from olives and olive oil. Medicinal Research Reviews, 22, 65-75. doi:10.1002/med.1028

[25] Ruiz-Gutiérrez, V., Vázquez, C.M. and Santa-Maria, C. (2001) Liver lipid composition and antioxidant enzyme activities of spontaneously hypertensive rats after ingestion of dietary fats (fish, olive and high-oleic sunflower oils). Bioscience Reports, 21, 271-285. doi:10.1023/A:1013277914213

[26] Sinclair, A.J., Begg, D., Mathai, M. and Weisinger, R.S. (2007) Omega 3 fatty acids and the brain: Review of studies in depression. Asia Pacific Journal of Clinical $\mathrm{Nu}$ trition, 16, 391-397.

[27] De Lau, L.M.L., Bornebroek, M., Witteman, J.C.M., Hofman, A., Koudstaal, P.J. and Breteler, M.M.B. (2005) Dietary fatty acids and the risk of Parkinson disease. Neurology, 64, 2040-2045. doi:10.1212/01.WNL.0000166038.67153.9F

[28] Zaslaver, M., Offer, S., Kerem, Z., Stark, A.H., Weller, J.I., Eliraz, A. and Madar, Z. (2005) Natural compounds derived from foods modulate nitric oxide production and oxidative status in epithelial lung cells. Journal of Agricultural and Food Chemistry, 53, 9934-9939. doi:10.1021/jf052000u

[29] Tony, V., Juan, H., Irene, Bolea., Bartolomé, Ramirez., Neus, A., Jordi, R., José, R.M., Cristina, G., Mercè, B. and Mercedes, U. (2009) A diet enriched in polyphenols and polyunsaturated fatty acids, LMN diet, induces neurogenesis in the subventricular zone and hippocampus of adult mouse brain. Journal of Alzheimer's Disease, 18.

[30] Schaffer, S., Podstawa, M., Visioli, F., Bogani, P., Müller, W.E. and Eckert, G.P. (2007) Hydroxytyrosol-rich olive mill wastewater extract protects brain cells in vitro and ex vivo. Journal of Agricultural and Food Chemistry, 55, 5043-5049. doi:10.1021/jf0703710

[31] Nevo, E., Shimony, T. and Libin, M. (1978) Pollution selection of allozyme polymorphisms in barnacles. $E X$ perentia, 36, 1562-1564. doi:10.1007/BF02034674

[32] Tolba, M.R., Mohammed, B. and Mohammed, A. (1997) Effect of some heavy metals on respiration, mean enzyme activity and total protein of the pulmonate snails Biomphalaria alexandrina and Bulinus truncates. Journal of Egyptian German Society of Zoology, 24, 17-35.

[33] Farkaset, J., Farkas, P. and Hyde, D. (2004) Liver and gastroenterology tests, ini basic skills in interpreting laboratory data. Mary Lee 3rd Edition, American Society of Health System Pharmacists, Bethesda, Maryland, USA, 330-336.

[34] Alhazza, I.M. (2007) Antioxidant and hypolipidemic effects of olive oil in normal and diabetic male rats. Saudi Journal of Biological Sciences, 14, 69-74. 